\title{
EGZEGEZA BIBLIJNA W KOMENTARZACH SYRYJSKICH AFRAHATA, EFREMA, ISZODADA Z MERW I TEODORA BAR KONI
}

\section{Zarys problematyki}

Istotny problem egzegezy biblijnej tkwi w istnieniu paralelnych relacji tych samych wydarzeń. O ile różnice w dublowanych historiach przekazanych w Starym Testamencie (por. 1Sm 16, 14-23 i 1Sm 17, 12-57; Wj 20, 3-17 i Pwt 5, 7-21) nie stanowią centrum problematyki, o tyle nieporównanie większe trudności interpretacyjne stwarzają opisy życia Jezusa zanotowane zwłaszcza w Ewangeliach synoptycznych. W celu rozwiązania tych egzegetycznych dylematów Tacjan Syryjczyk, a przed nim Justyn Męczennik, zastosowali metodę harmonizacji wielu różniących się przekazów w jedną spójną relację. Marcjon użył innego narzędzia, przyjmując jedynie wersję św. Łukasza we własnym opracowaniu. Komentatorzy syryjscy podjęli wyzwanie w oryginalny sposób, rzadko spotykany w łacińskiej i greckiej egzegezie. Prawdopodobnie z powodu ich mentalnej bliskości z judaizmem i znajomości egzegetycznego warsztatu pracy Żydów, Syryjczycy przyjęli formę komentarzy, dzięki której mogli ustawić obok siebie nie tylko różne i wykluczające się interpretacje, ale nawet różne i sprzeczne wersje tego samego wydarzenia ${ }^{1}$. Warto bliżej przyjrzeć się tej syryjskiej metodzie egzegetycznej, jej genezie i dokładniej zbadać wątki teologiczne stojące u podstaw jej harmonizującej celowości, aplikowanej w interpretacji tekstów zarówno Starego, jak i Nowego Testamentu. Przedmiotem analizy będą wybrane fragmenty dzieł Afrahata i Efrema z Edessy oraz te ustępy wschodniosyryjskich komentarzy z VIII i IX w., które przez formalno-treściowe podobieństwo do tych pierwszych mogą dowodzić ewentualnej kontynuacji w procesie rozwoju orientalnej egzegezy biblijnej. Ogromny wpływ Teodora z Mopsuestii na formę i teologiczną zawartość nestoriańskich

${ }^{*}$ Ks. dr hab. Andrzej Uciecha - adiunkt w Katedrze Teologii Patrystycznej i Historii Kościoła na Wydziale Teologicznym Uniwersytetu Śląskiego w Katowicach; e-mail: andrzej.uciecha@wp.pl.

${ }^{1}$ Por. W.L. Petersen, Problems in the Syriac New Testament and how Syrian Exegetes solved them, w: The Peshitta. Its use in literature and the liturgy. Papers Read at the Third Peshitta Symposium, ed. Bas ter Haar Romeny, Leiden - Boston 2006, 64-65. 
dzieł egzegetycznych nie podlega dyskusji. W naszych analizach zasygnalizowane zostaną tylko wybrane opinie tego interesującego zagadnienia ${ }^{2}$.

1. Egzegeza biblijna w dziełach Afrahata. Zdaniem Perskiego Mędrca podstawową trudnością w komentowaniu Pisma Świętego jest ograniczona zdolność ludzkiego umysłu w poznaniu Boga i Jego stworzenia. W Demonstrationes Afrahat nawiązuje do starotestamentalnej koncepcji ksiąg mądrościowych. Istota ludzka może próbować opisać Stwórcę tylko na podstawie przejawów Jego stwórczego działania. Ten, kto pragnie poznać tajemnice Stwórcy, musi się odpowiednio przygotować i nie ustawać w trudzie stawania się „uczniem świętych Pism”. Wymaga to podporządkowania się precyzyjnie określonym zasadom, których konsekwentne przestrzeganie stanowi niezbędny warunek zdobywania mądrości. Konieczna jest dyscyplina i zachowanie umiaru w poznaniu Boga. Przesada prowadzi do zamieszania w odkrywaniu prawdy:

„Gdy człowiek chce Cię określić, brakuje mu [wiele], nawet gdy wysila swój umysł, to nie wystarczy; jeśli unosi się inteligencją aż ponad niebiosa, [i tak] znajduje siebie maszerującego po ziemi. Jeśli nawet jego myśl zstępuje na chwilę w głębiny, on odwraca się ku swojej ziemi, a jego refleksja ustaje. Czy jest ktoś, kto mógłby sięgnąć ponad niebiosa? I nie ma nikogo, kto mógłby powiedzieć, co jest pod ziemią; i na czym rozciaga się firmament? I na czym zawieszone są niebiosa? I na czym wspiera się ziemia? I jak umocowana jest głębina?"4

Potomkowie Adama, stworzonego z prochu ziemi, mogą stwierdzić jedynie, że Bóg jest jeden, jeden jest Chrystus i jeden Duch ${ }^{5}$. Takie proste stwierdzenie zawierające podstawowe prawdy wiary wydaje się mądrym rozwiązaniem i wynika ze świadomości ograniczonych zdolności człowieka, jak i szkodliwości przesadnego wnikania w niezgłębione tajemnice Stwórcy ${ }^{6}$. Istota Stwórcy znajduje odzwierciedlenie w naturze Jego Słowa:

„Wszystko to, o czym Ci pisałem, mój przyjacielu, i co jest napisane u Daniela nie wypełniło się, lecz jeszcze daleko do końca. Jeśli ktoś kłóciłby się na ten temat, powiedz mu tak: «Słowa te nie są jeszcze opieczętowane, ponieważ

\footnotetext{
${ }^{2}$ Por. C. Leonhard, Ishodad of Merw's Exegesis of the Psalms 119 and 139-147: A Study of His Interpretation in the light of the syriac translation of Theodore of Mopsuestia's Commentary, CSCO 585, Scriptores Syri 107, Lovanii 2005.

${ }^{3}$ Por. Aphraates, Demonstratio 22, 26, ed. J. Parisot: Aphraatis Sapientis Persae Demonstrationes, PSyr 1, Paris 1894, 1980², 1044, 21 - 1049, 19 (1049, 3-4: „,uczeń świętych Pism”).

${ }^{4}$ Tenże, Demonstratio 23, 59, ed. J. Parisot, PSyr 2, Paris 1907, 1980², 121, 24 - 124, 9.

${ }^{5}$ Por. tenże, Demonstratio 23, 60, PSyr 2, 124, 10-21; podobnie niezgłębiona jest tajemnica bóstwa Ojca i chwały Syna, zob. tenże, Demonstratio 6, 11, PSyr 1, 284, 1 - 285, 14, thum. A. Uciecha: Afrahat, O synach przymierza (Demonstratio sexta. De monachis, PSyr 1, 240-312), SSHT 44 (2011) fasc. 1, 190.

${ }^{6}$ Por. tenże, Demonstratio 10, 8, PSyr 1, 460, 19 - 461, 19.
} 
słowa Boga są nieskończone i nigdy nie są opieczętowane». Nie wolno jednak do nich niczego dodać ani im ująć (por. Pwt 4, 2). Bogactwo Boże bowiem jest niewyobrażalne i nieskończone. Jeśli weźmiesz wody z morza, nie zauważy się żadnego umniejszenia; i jeśli weźmiesz piasku z jego [morza] brzegu, jego ilość nie umniejszy się. Jeśli chciałbyś zliczyć gwiazdy na niebie, nie wytrwasz do ich końca. Jeśli zapalisz ogień od ogniska, ono wcale nie stanie się mniejsze. I jeśli weźmiesz z Ducha Chrystusowego, Chrystus w niczym nie zostanie pomniejszony. Jeśli Chrystus zamieszka w tobie, w niczym nie będzie ograniczony przez ciebie. Jeśli słońce wchodzi przez okna Twego domu, to nie jest to całe słońce, które do ciebie dociera. To wszystko, co wyliczyłem Ci, zostało stworzone przez Słowo Boże. Dlatego też trzeba Ci wiedzieć, że nikt jeszcze nie dotarł, ani nie może dotrzeć do końca Słowa Bożego. Z tego powodu nie wolno kłócić się o to, lecz należy mówić: tak to jest i niech wystarczy. Słuchaj tego, co moje, i thumacz to naszym braciom, synom naszej wiary. Tego, kto drwi sobie ze słów swego brata, lub uważa, że jego są mądrzejsze, nie należy słuchać. Tego, co napisałem Ci na temat wojska gromadzonego na wojnę, nie wyjaśniałem Ci jako czegoś, co zostało mi objawione. Słuchaj jednak słów, które są na początku listu: «Każdy, kto się wywyższa, będzie poniżony» (Łk 14, 11)"’7.

Bogactwo Bożego Słowa jest nieskończone i niewyczerpalne tak, jak jego źródło, z którego pochodzi, czyli sam Bóg. Głoszenie Słowa wymaga cierpliwości i pokory. Wszelkie zapowiedzi i proroctwa objawione w ,świętych Pismach" zrealizują się ostatecznie i w pełni dopiero na końcu czasów. Wątek eschatologiczny odgrywa istotną rolę w nauczaniu perskiego Mędrca, który swoje Demonstrationes skierował przede wszystkim do „synów przymierza”.

Od „ucznia świętych Pism” wymaga się również, aby szukał i słuchał mądrych nauczycieli. Bez pomocy takich przewodników jak król Dawid, prorok Daniel $^{8}$, czy św. Pawe1 ${ }^{9}$, zrozumienie biblijnego przesłania jest niemożliwe. Opisując bogactwo Słowa Bożego, Afrahat wykorzystuje klasyczny obraz perły:

„Jeśli więc zapyta o te kwestie, które są zbyt trudne dla niego, [wtedy] mądrzy tłumacze, którzy badają naukę, gdy będzie ich dziesięciu, opowiedzą mu o dziesięciu twarzach/obliczach (حصن مهب) jednego słowa, i otrzyma to,

\footnotetext{
${ }^{7}$ Por. tenże, Demonstratio 5, 25, PSyr 1, 236, 7 - 237, 14, thum. A. Uciecha: Afrahat, O wojnach (Demonstratio quinta. De bellis, PSyr 1, 184-237), SSHT 43 (2010) fasc. 2, 261.

${ }^{8}$ Afrahat (Demonstratio 5, 14, PSyr 1, 209, 25 - 212, 3, thum. Uciecha, s. 256) podkreśla mądrość proroka Daniela, który umiejętnie wyjaśniał królewską wizję.

${ }^{9}$ Por. tenże, Demonstratio 22, 26, PSyr 1, 1048, 7-12: „Jeśli chcesz się uczyć, przypomnij sobie, co powiedział Dawid: «Uczyłem się od wszystkich moich nauczycieli» (Ps 119, 99) i co rzekł Apostoł: «Wszystko, co napisane jest według Ducha Bożego, czytaj!; i badaj wszystko, zachowując, co dobre i unikając wszelkiego rodzaju zła» $(2 \mathrm{Tm} 3,16)$ ", thum. własne. We wszystkich 23 Mowach Afrahat pozostaje wierny argumentacji biblijnej, w której pozytywnymi wzorami do naśladowania są postaci ludzi sprawiedliwych, zaś postępowanie niesprawiedliwych stanowi równie pouczający przykład zaprzeczenia i odrzucenia Bożej mądrości.
} 
co jest w stanie [przyjąć], aby z powodu tego, czego nie jest w stanie [przyjaćc], nie kpił sobie z mędrców. Słowo Boże bowiem jest podobne do perły (נ) : z każdej strony, gdy ją obracasz, jest piękna"10.

Przejawem mądrości i niepojętej głębi ukrytej w Piśmie Świętym jest akceptacja różnych interpretacji i poglądów; chociaż jest ich wiele i różnią się one między sobą, każda propozycja godna jest uwagi. Należy jednak pamiętać, że bez stosownego przygotowania i pomocy doświadczonych „mędrców” - egzegetów niewprawny czytelnik może wybrać wersję fałszywą. Dlatego Afrahatowa pochwała różnorodności w biblijnej egzegezie ma swoje granice i daleka jest od głoszenia niebezpiecznego subiektywizmu:

„Otóż gdyby człowiek żył tyle dni, ile liczy świat od Adama aż do końca czasów, i gdyby siedział i rozważał święte Pisma, [to i tak] nie będzie w stanie zrozumieć najgłębszego sensu słów. Bożej mądrości nikt nie może zgłębić, jak już pisałem Ci w dziesiątej mowie. Słowa wszystkich tych głosicieli/ mówców (riçr) $)^{11}$, którzy nie biorą z wielkiego skarbca, zostaną wzgardzone i odrzucone. Wizerunek króla bowiem przyjmuje się w całym kraju, gdziekolwiek się udać, lecz jeśli się znajdzie fałszywa moneta, wyrzuca się ją i [uważa] za odpadek. Ktoś [może] powie: «W tych mowach przemawia ktoś, kto zadowala się uczeniem się, ale nie jest obciążony troskami głosiciela (مic)». Otóż, napisałem Ci to, jako słaby człowiek zrodzony z Adama i ukształtowany rękami Boga, ponieważ jestem uczniem świętych Pism. Nasz Pan rzekł: «Kto prosi, otrzymuje, kto szuka, znajduje, a temu, kto puka, otworzą» (Mt 7, 8), a prorok powiedział: «Wyleję Ducha mego na wszelkie ciało» w dniach ostatecznych, «i będą prorokować» $(\mathrm{Jl} 3,1){ }^{» 12}$.

Dla Afrahata wyjaśnianie zawiłych problemów hermeneutycznych w przekazie Bożych tajemnic nie jest zadaniem łatwym. Pers zastrzega, że jego wykłady nie powstały na podstawie opinii jednego tylko nauczyciela, ale ich źródłem jest przekonanie całego Kościoła i wszystkich wierzących ${ }^{13}$. Aprobata różnorodności biblijnych komentarzy świadczy o znajomości istoty Pisma Świętego. Równocześnie jednak należy uważać na tych, „którzy nie biorą z wielkiego skarbca". Prawdopodobnie Pers wskazywał na błędy heretyków: marcjonitów, walentynian i manichejczyków ${ }^{14}$ albo też na kapłanów

${ }^{10}$ Tamże, PSyr 1, 1045, 26 - 1048, 7, tłum. własne. Na temat wykorzystania obrazu perły w dziełach gnostyckich i manichejskich, por. W. Myszor, Sprzedawca peret w „Dziejach Piotra i dwunastu Apostołów" z VI Kodeksu z Nag Hammadi, VoxP 7 (1987) t. 12-13, 303-305, tenże, Symbolika perly w utworach gnostyków i manichejczyków, „Rocznik Muzeum Narodowego w Warszawie" 36 (1992) 41-48.

${ }^{11}$ Por. Thesaurus Syriacus, ed. R. Payne Smith, t. 1, Oxonii 1879, 245, Riarr - ,dicens”, „qui dicit”, ,orator”, „,cantor”.

${ }^{12}$ Aphraates, Demonstratio 22, 26, PSyr 1, 1048, 12 - 1049, 8, thum. własne.

${ }^{13}$ Por. tamże, PSyr 1, 1044, 25 - 1045, 2.

${ }^{14}$ Por. tenże, Demonstratio 3, 9, PSyr 1, 116, 4-17, thum. A. Uciecha: Afrahat, O poście (Demonstratio tertia. De ieiunio, PSyr 1, 97-136, SSHT 42 (2009) fasc. 1, 92. 
zaratustrianizmu, który wówczas był religią państwa perskiego. Ta druga hipoteza wydaje się bardziej prawdopodobna.

Zdaniem Marie-Joseph Pierre w egzegetycznej metodzie Afrahata widoczne są wyraźne wpływy egzegezy żydowskiej. W tradycji rabinicznej każde słowo Tory posiada 600000 twarzy zgodnie z liczbą Izraelitów na pustyni Synaj (por. Wj 12, 37; Lb 11, 21) ${ }^{15}$.

2. Egzegeza biblijna w dziełach Efrema. Podobnie jak Afrahat również Diakon z Edessy wykorzystuje w swoim warsztacie egzegetycznym obraz perły $^{16}$. W Hymnach o wierze za pomocą tego najbardziej ulubionego porównania rozwija on różnorodne watki teologiczne oraz wskazuje trudności w ludzkim poznawaniu Bożych tajemnic. Warto je przedstawić, gdyż ułatwią zrozumienie istoty i oryginalności biblijnych komentarzy Syryjczyka.

„Pewnego dnia, moi bracia, wziąłem perłę (słw). I spostrzegłem

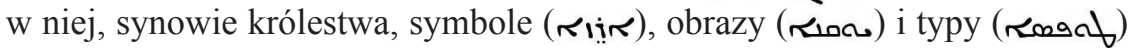
tego Majestatu. I stała się źródłem. I ugasiłem pragnienie (んðょん) tajemnicami Syna. Refren: Błogosławiony jest ten, który porównał królestwo Najwyższego do perły. I położyłem ją, moi bracia, na mojej dłoni, aby lepiej ją zbadać. I zabrałem się do przyglądania się jej z jednej strony. Ale ona miała swoje oblicze na każdej stronie ${ }^{17}$. Podobnie obserwujemy Syna, Tego, którego [tajemnicy] nie można zgłębić, ponieważ On jest całkowitym światłem"18.

Efrem nie porównuje perły do Słowa Bożego, jak to czyni Afrahat, ale do samego Chrystusa, który stał się człowiekiem. W nieprzeniknionym świetle tajemnicy Jego bóstwa ukrywają się prawda i czystość. W konfrontacji z tą tajemnicą ograniczone możliwości ludzkiego umysłu należy podporządkować ściśle określonym zasadom biblijnej egzegezy ${ }^{19}$. Blask, którym perła błyszczy

${ }^{15}$ Por. Aphraate le Sage Persan, Les Exposés, t. 2: Exposés XI-XXIII, trad. du syriaque, introduction et notes par M.-J. Pierre, SCh 359, Paris 1989, 872, nota 78.

${ }^{16}$ Temat perły występuje w Hymnie o perle włączonym do apokryficznych Dziejów Apostoła Judy Tomasza, por. Acta Judae Thomae 108-113B, ed. W. Wright: The Hymn of Judas Thomas the Apostle in the country of the Indians, w: Apocryphal Acts of the Apostles, vol. 1: The Syriac Texts, London, 1871, $\mathbf{x}$ - 女i; tłum. M. Starowieyski: Dzieje Apostoła Judy Tomasza, w: Apokryfy Nowego Testamentu. Apostołowie, część I: Andrzej, Jan, Pawel, Piotr, Tomasz, red. M. Starowieyski, Kraków 2007, 652-659.

${ }^{17}$ R. Payne Smith (Thesaurus Syriacus, t. 1, s. 278) thumaczy: „tibi semper similis es et constans, O margarita, lit. Facies tu tota es, h.e. ubiqunque aliquis te inspiciat, id latus tua facies est, quum rotunda es”. Przekład Becka (Des Heiligen Ephraem des Syrers „Hymnen de Fide”, CSCO 155, Scriptores Syri 74, Louvain 1955, 211) w zwrotce 2, wiersz 3: „Sie widersetzte sich” - wydaje się niezrozumiały. Jak uważa F. Graffin (Les Hymnes sur la Perle de S. Ephrem, „L'Orient Syrien” 12 (1967) 132), niemiecki badacz sugerował się thumaczeniem „restitit” Carla Brockelmanna podanym w Lexicon Syriacum, Halis Saxonum 1928, 39.

${ }^{18}$ Ephraem Syrus, Hymnus de fide 81 (De Margarita I), 1, ed. E. Beck, CSCO 154, Scriptores Syri 73, Louvain 1955, 248, tłum. własne.

${ }^{19}$ Por. E.G. Mathews Jr. - J.P. Amar, General introduction, w: St. Ephrem the Syrian, Selected 
z każdej swojej strony, może podziwiać tylko ten, kto nie boi się spoglądać $\mathrm{w}$ to światło ${ }^{20}$. Wymagana jest czystość spojrzenia ${ }^{21}$. To moralnie skoncentrowane wpatrywanie się oznacza intelektualne poszukiwanie, które staje się możliwe dzięki obecności Ciała Pańskiego (a ( ne dla śmiertelnika ${ }^{22}$.

Hermeneutycznym kluczem w egzegetycznym warsztacie Efrema jest koncepcja symbolu (rir) $)^{23}$. Zdaniem El-Khoury'ego zakres semantyczny tego pojęcia wskazuje na połączenie przedmiotu z wizualizowanym obrazem i jest czymś, co można rozpoznać. Ta możliwość poznania jest podstawową cechą symbolicznego wyrazu. Symbol nie przyjmuje swojego znaczenia w relacji do znaczenia czegoś innego, posiada bowiem swój własny i wyraźny sens. Przez swoją manifestację to symbol przenosi znaczenie na coś innego, przez co może być ono rozpoznawane. Dzieła Efrema, zwłaszcza poetyckie, wyraźnie świadczą o wykorzystaniu symbolizmu strukturalnego i treściowego. W jego bogatej terminologii widoczne są różnice w symbolicznym znaczeniu. Wyjaśnieniem sensu symbolu jest pojęcie rir: oznacza ono sposób zrozumienia, który można uchwycić za pomocą zmysłów, ale który kieruje zrozumienie do abstrakcyjnego ideału, ukrytego przed percepcją zmysłową ${ }^{24}$. W teologii Efrema wszystkie symbole znajdują swoje wypełnienie w Chrystusie. To On odsłania ich prawdziwe znaczenie. On jest „Panem symboli”25 i „Skarbnicą wszelkich symboli”"26.

W swoim komentarzu do Diatessaronu ( $\delta i \grave{\alpha} \tau \varepsilon \sigma \sigma \alpha ́ \rho \omega v)$ Efrem z Nisibis podaje kilkanaście różnych znaczeń ukrytych w symbolice rozerwanej zasłony przybytku. Scena ta może symbolizować odebranie królestwa narodowi

Prose Works (Commentary on Genesis, Commentary on Exodus, Homily on our Lord, Letter to Publius), The Fathers of the Church 91, transl. E.G. Mathews Jr. - J.P. Amar, ed. K. McVey, Washington 1994, 54.

${ }^{20} \mathrm{Na}$ temat potęgi i tajemnicy Bożej chwały adorowanej przez aniołów, zob. Ephraem Syrus, Hymnus de fide 4, 11, CSCO 154, 13; 4, 13, CSCO 154, 14.

${ }^{21} \mathrm{~W} 3$ strofie hymnu 81. Efrem za pomocą pojęć określających czystość, jasność, klarowność

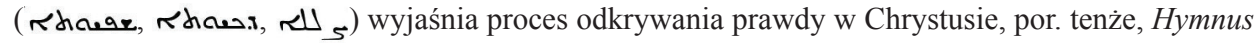
de fide 81 (De Margarita I), 3, CSCO 154, 249. Na temat zastosowania paralelizmów morfologicznych, syntaktycznych i brzmieniowych w tej 3 strofie, por. A.S.R. Pereira, Studies in Aramaic Poetry (c. 100 B.C.E.-c.600 C.E.). Selected Jewish, Christian and Samaritan Poems, Assen 1997, 242-243.

${ }^{22}$ Por. Ephraem Syrus, Hymnus de fide 81 (De Margarita I), 3, CSCO 154, 249.

${ }^{23}$ Por. Thesaurus Syriacus, ed. R. Payne Smith, t. 2, Oxonii 1901, 3871-3872, riir - „secretum”, ,arcanum”, „mysterium”, „typus”, ,figura”, ,significatio mystica”, ,symbolum”.

${ }^{24}$ Pojęcie Rıir jest używane zamiennie z rhass (obraz) lub rhine (podobieństwo, parabola), ale ciagle zachowuje sens rosa of (typ) i ran. (ikona), por. N. El-Khoury, Hermeneutics in the Works of Ephraim the Syrian, w: IV Symposium Syriacum, OCA 229, Roma 1987, 93-94.

${ }^{25}$ Por. Ephraem Syrus, Hymnus de fide 9, CSCO 154, 46.

${ }^{26}$ Por. tenże, Commentarius in Evangelium I 1-2, 1.5 (wersja armeńska) = 2, 1. 5-3 (wersja syryjsko-armeńska), tłum. francuskie L. Leloir: Éphrem de Nisibe, Commentaire de L'Évangile Concordant ou Diatessaron, SCh 121, Paris 1966, 42. 
wybranemu i przekazanie go poganom. Może też oznaczać zniszczenie świątyni, którą opuścił Duch. Równie dobrze wskazuje na pouczające działanie Ducha, który zniszczeniem odpowiada na rozerwane szaty arcykapłana i bezwstydną pychę Żydów:

„Albo te $\dot{z}^{27}$ Bóg rozerwał zasłonę, gdyż Żydzi zdarli szaty Pana. Ich serca nie nawróciły się i dlatego serce skały pękło. [...] Albo też w innej interpretacji usta stworzeń ogłosiły niewinnym Pana, ponieważ usta człowieka potępiły go. Żydzi zamilkli, ale kamienie zaczęły wołać, jak to On powiedział. Zasłona rozerwała ich zatkane uszy i oddała chwałę Panu, którego oni odrzucili. Albo też Duch widząc Syna ukrzyżowanego i obnażonego, pochwycił i rozerwał zasłonę, która była odzieniem chwały. Albo też duch prorocki, który przebywał w świątyni, zstapił zapowiadając swoje przyjście do ludzi, uniósł się nagle, aby ogłosić na wysokościach, że Pan wstąpił do nieba"28.

Wzmiankę o otwarciu grobów Efrem interpretuje jako znak mocy Chrystusa, który potrafi złamać drzewo krzyża, ale nie czyni tego, zachowując swoją siłę, aby pokonać królestwo Izraela i zniszczyć grzech pośród pogan. W kolejnej wersji interpretacyjnej komentator wraca do działania Ducha, który to zniszczył zasłonę zamiast drzewa krzyża i aby ukazać opuszczenie świątyni, powołał na świadków swojego wyjścia sprawiedliwych i świętych, którzy wyszli z grobów. Zdaniem Efrema te dwa wyjścia Chrystusa i sprawiedliwych są komplementarne i ściśle z sobą związane. Objęcie urzędu króla i kapłana było związane z namaszczeniem i uświęceniem w Duchu, który jest źródłem tych dwóch funkcji. Duch wyniósł je, opuszczając świątynię. I w ten sposób pokazał, że to przez niego zostały one wyczerpane ${ }^{29}$.

Zauważmy, że Syryjczyk nie klasyfikuje i nie wyróżnia wymienionych interpretacji, nie ocenia ich walorów teologicznych ani pedagogicznych, ani jakichkolwiek innych, ale zwyczajnie przedstawia je jako równie ważne wersje. Możliwość wyboru zależy od przygotowania odbiorcy i stanu jego percepcji. Efrem zupełnie pomija fakt chronologicznej nieścisłości w narracji Mateusza, w której wraz ze śmiercią Chrystusa święci mieli opuścić groby „po Jego zmartwychwstaniu" (por. Mt 27, 52-53).

\section{Egzegeza biblijna w syryjskich komentarzach Iszodada z Merw} i Teodora bar Koni. W literaturze syryjskiej większość komentarzy ma charakter selektywny. Ich autorzy w sposób wyraźnie wybiórczy dokonują autorskiej selekcji komentowanego materiału i nie cytują wszystkich wierszy biblijnych analizowanych perykop. We wczesnym okresie Efrem Syryjczyk przestrzega zasad literackiej spójności, dołączając wyjaśniające wprowadzenia lub

${ }^{27}$ Zaproponowane w tym fragmencie thumaczenie ,,albo też” z przekładu francuskiego „ou bien”.

${ }^{28}$ Tamże XXI 3-4, 1.9 (wersja armeńska) = 4, 1. 9, - 6 (wersja syryjsko-armeńska), SCh 121, 376-377, thum. własne.

${ }^{29}$ Por. tamże XXI 6-10 (wersja syryjsko-armeńska), SCh 121, 378. 
łączące sentencje i paragrafy. W późniejszych jego komentarzach uderza brak autorskich prób takiej literackiej koherencji. Często natomiast stosowanym narzędziem jest użycie formuły typu id est $\sim m$, za pomocą której autor wprowadza wyjaśniającą notę lub dłuższy fragment jako parafrazę biblijnego tekstu albo analizę badanego tematu. Oprócz takich standardowych komentarzy istnieją również opracowania sformatowane w strukturze pytanie-odpowiedź. Komentarze późniejszego okresu cechuje bardziej encyklopedyczna natura. Ich treściową zawartość stanowią kolacjonowane uwagi i wyjaśnienia różnej zawartości i pochodzenia, które w dzisiejszej pracy redakcyjnej umieścić należałoby w przypisach ${ }^{30}$.

We wschodniosyryjskiej tradycji należy uwzględnić znaczne oddziaływanie Teodora z Mopsuestii, najważniejszego autorytetu w biblijnej tradycji wschodniosyryjskiej zwanego Interpretator-Nauczyciel (ninras) ${ }^{31}$. Jego komentarze miały istotny wpływ na późniejsze interpretacje biblijne. Proces adaptacji tych komentarzy do syryjskiego kontekstu musiał rozpocząć się już w najwcześniejszych przekładach dzieł interpretatora w V w. Zdaniem Lucasa Van Rompay'a w VIII i IX w. syryjskie komentarze bazują całkowicie na tekście Peszitty. Ich autorzy są w posiadaniu narzędzi, w tym także alternatywnych cytatów wyraźnie przypisanych LXX, za pomocą których wypełniają możliwą przepaść między Peszittą a grecką podstawą komentarzy Teodora. Bardzo interesujące w badaniu historii Peszitty i jej zastosowania są komentarze Iszodada z Merw, i to nie jedynie dlatego, że odzwierciedlają specyficzny okres w historii ewolucji tekstu. Nestoriański egzegeta jest świadkiem w rozwoju Peszitty i często podaje różne wersje lektury jej tekstu ${ }^{32}$.

a) Iszodad z Merw. Pochodził z miasta Merw (Maru; dzisiejszy Turkmenistan). Został biskupem w Hedatta (Hdatta, al-Hadītha; miasto położone na południowy-wschód od Mosulu) ok. roku 837. Jego komentarz do Pisma Świętego uznawany jest wśród nestorian za jeden z wybitniejszych, zawiera fragmenty z dzieł wcześniejszych egzegetów syryjskich i greckich [Efrem Syryjczyk, Teodor z Mopsuestii, Henana z Adiabene († 610), Dadiszo Qatraya (VII w.), Bazyli z Cezarei, Jan Chryzostom]. Jak twierdzi Alison Salvesen, Iszodad komentował syryjski tekst Biblii w wersji biskupa Pawła z Teli. Ten przekład zwany Syro-Hexaplą został wprowadzony do wschodniosyryjskiego Kościoła ok. 800 r. Teolog z Merw był pierwszym egzegeta, który z tej biblijnej wersji cytował zarówno LXX, jak i umieszczone w niej

${ }^{30}$ Por. L. Van Rompay, Between the school and the monk's cell: the syriac Old Testament commentary tradition, w: The Peshitta, s. 31.

${ }^{31} \mathrm{~W}$ zakresie semantycznym tego pojęcia zawiera się sens objaśniania, ułatwiania zrozumienia, por. L. Costaz, Dictionnaire Syriac-Français, Beyrouth 1986², 294.

${ }^{32}$ Por. Van Rompay, Between the school and the monk's cell, s. 37-38; T. Jansma, Théodore de Mopsueste. Interprétation du „Livre de la Genèse”. Fragments de la version syriaque (B.M. Add. 17, 189, fol. 17-21), „Muséon” 75 (1962) 82-83; Leonhard, Ishodad of Merv's Exegesis of the Psalm 119 and 139-147, s. 40-42. 
greckie thumaczenia Akwili, Symmacha i Teodocjona ${ }^{33}$. Jako przedstawiciel antiocheńskiej tradycji egzegetycznej Iszodad posługuje się zasadniczo sensem wyrazowym i historycznym, jednak w komentarzach do ksiag poetyckich (Pnp; Hi) swobodnie wykorzystuje także język przenośni. Jego próby asymilacji elementów obcych metodom szkoły w Nisibis świadczą o ewolucji w egzegezie nestoriańskiej i podkreślają bogactwo piśmiennictwa wschodnich Syryjczyków w Mezopotamii ${ }^{34}$.

Komentując Chrystusowe pouczenia zawarte w mowie misyjnej (por. Mt 10, 16), Iszodad wyjaśnia symbolikę węża (r hoow

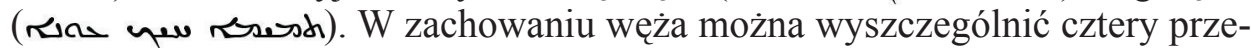
jawy roztropności. Otóż gdy ten gad się starzeje, a jego skóra uciska go i jego oczy ślepną, wtedy pości przez czterdzieści dni, aż jego ciało rozluźnia się. Następnie szuka szczeliny prostej i wąskiej, i wciska się w nią, zrzucając swoją starą skórę. W ten sposób odmładza się i nabiera siły. Zdaniem komentatora W tym obrazie (כתחוא Chrystus wzywa głosicieli Ewangelii, aby wchodzili przez ciasną bramę życiowych doświadczeń (por. Mt 7, 13) i aby zrzucali z siebie starego człowieka, który zestarzał się przez grzechy. Chrystusowy wysłannik powinien odnawiać się przez odkrywanie podobieństwa do swojego Stwórcy. Druga cecha widoczna jest, gdy wąż wypełza i szuka wody w rzece, aby się napić. Iszodad twierdzi, że na ten czas poszukiwań zwierzę zostawia swoje zęby w norze. Ma to znaczyć, że apostołowie Chrystusa nie podtrzymują gniewu ani wściekłości przeciwko swoim prześladowcom oraz wtedy, gdy idą pić wodę życia wiecznego, nie zabierają zębów cielesnych uciech i nieczystości. Trzeci przymiot charakteryzuje zachowanie węża reagującego w zależności od tego, czy spotyka na drodze człowieka ubranego czy nagiego: tego ostatniego się boi i ucieka przed nim, gdy zaś widzi go odzianego, nie obawia się i atakuje go. W tym porównaniu ukrywa się Chrystusowe wezwanie do zrzucenia odzienia z grzesznych namiętności, tak aby nasz wróg, Zły, który nas nienawidzi, nie zaatakował nas. Czwarta cecha węża widoczna jest w sytuacji, gdy chce on uderzyć. Wtedy syczy i napina całe swoje ciało, jednak chroni swój łeb, który zapewnia życie całemu organizmowi. Chrystus naucza w ten sposób, aby apostołowie znosili wszelkie udręki i choroby, aż do

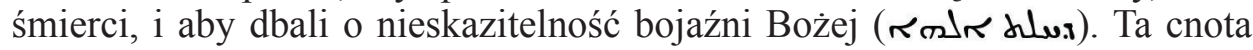

${ }^{33}$ Por. A.G. Salvesen, Syro-Hexapla, w: Gorgias Encyclopedic Dictionary of the Syriac Heritage, ed. S.P. Brock - A.M. Butts - G.A. Kiraz - L. Van Rompay, Piscataway 2011, 394-395; A. Baumstark, Geschichte der syrischen Literatur mit Ausschluss der christlich-palästinensischen Texte, Bonn 1922, 186-188. Kwestię, z której wersji Syro-Hexapli korzystał Iszodad, sygnalizuje Willem Baars (New Syro-Hexaplaric Texts. Edited, Commented upon and Compared with the Septuagint, Leiden 1968, 2 i 146-147).

${ }^{34}$ Por. B. Modzelewska, Iszodad z Merw, EK VII 542-543; M. Starowieyski, Iszodad z Merw, SWPW 96; L. Van Rompay, Isho 'dad of Merv (floruit circa 850) [Church of the East], w: Gorgias Encyclopedic Dictionary of the Syriac Heritage, s. 216-217; W. Wright, A Short History of Syriac Literature, London 1894, 220-221.

${ }^{35} \mathrm{O}$ zachowaniu i symbolice węża, por. Pseudo-Epiphanius, Physiologus, PG 43, 528B - 529B. 
jest szczytem ziemskiego życia chrześcijanina. Podobnie jak wąż, który ginie, gdy traci głowę, tak uczeń Chrystusa traci zbawienie, gdy niszczy zdrową wiarę, która jest szczytem wszystkiego dobrego. Wszystkie podane zachowania

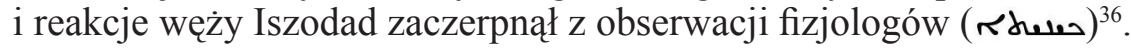

Przykład egzegetycznego stawiania obok siebie różniących się historycznych wersji wydarzeń znajdziemy w komentarzu Iszodada do Mt 27, 50-54. W relacji Mateusza Jezus właśnie zmarł na krzyżu i moment śmierci William Petersen nazywa „czasem realnym”. Towarzyszące tej śmierci nadzwyczajne i straszne zjawiska rozdarcia zasłony przybytku i trzęsienia ziemi dzieją się również w ,czasie realnym”. W opisie następnych konsekwencji natomiast widać zmianę ram czasowych: relacja na temat cudownych wydarzeń początkowo kontynuuje chronologię realną („Groby się otworzyły”, Mt 27, 52). Jednak w informacji powstania i wyjścia zmarłych z grobów pojawia się dziwny „poślizg” czasowy w przyjętej konstrukcji. Wskazówki „,czasu realnego” nagle zostają przesunięte o trzy dni („I wyszedłszy z grobów po Jego zmartwychwstaniu", Mt 27, 53). Widoczny jest brak konsekwencji, groby przecież musiałyby się otworzyć a święci powstać wtedy, gdy Jezus umarł na krzyżu, a jeszcze nie zmartwychwstał. W dalszym ciaggu ewangelicznej narracji o cudownym nawróceniu setnika i jego żołnierzy (por. Mt 27, 54) wracamy do „czasu realnego”. Możliwe, że ta chronologiczna niekonsekwencja była teologiczną korektą dokonaną w późniejszej rewizji tekstu, a wprowadzoną pod wpływem chrystologii św. Pawła (,Tymczasem jednak Chrystus zmartwychwstał jako pierwszy spośród tych, co pomarli. [...] lecz każdy według własnej kolejności. Chrystus jako pierwszy, potem ci, co należą do Chrystusa, w czasie Jego przyjścia", 1Kor 15, 20. 23) ${ }^{37}$.

Iszodad dostrzegł ten metodologiczno-teologiczny problem w przekazie ewangelicznym. W komentarzu do Ewangelii według św. Mateusza Syryjczyk wyjaśnia:

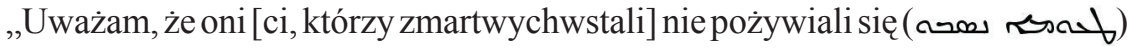
w ogóle [w ciagu trzech dni od otwarcia grobów], trzymani przy życiu dzięki Boskiej mocy, jak Mojżesz i Eliasz zachowywali post. Ale w piątek i w dzień szabatu, jak [mówia] niektórzy ( $<i v \kappa)$, powstali ze swoich grobów, aby oddać chwałę. Inni mówią, że zgromadzili się na Górze Oliwnej, na której modlił

${ }^{36}$ Por. Isho 'dad of Merv, In Matthaeum comm. VII (komentarz do Mt 10, 16), ed. M.D. Gibson, w: The Commentaries of Isho 'dad of Merv, Bishop of Hadatha (c. 850 A. D.) in Syriac and English, vol. 2: Matthew and Mark in Syriac, Horae Semiticae 6, Cambridge 1911, L - (76-77), thum. M.D. Gibson, w: The Commentaries of Isho 'dad of Merv, Bishop of Hadatha (c. 850 A. D.) in Syriac and English, Translation, vol. 1: Translation, Horae Semiticae 5, Cambridge 1911, 45-46. Rhew por. Thesaurus Syriacus, t. 1, s. 1704-1705. Na temat dzieła Fizjolog, por. K. Jażdżewska, O pochodzeniu ,Fizjologa”, WST 15 (2002) 85-100; Fizjologi i Aviarium. Średniowieczne traktaty o symbolice zwierzqt, tłum. i oprac. S. Kobielus, Kraków 2005 (symbol węża, por. tamże, s. 22-24).

${ }^{37}$ Por. Petersen, Problems in the Syriac New Testament and how Syrian Exegetes solved them, s. 66. 
się nasz Pan. Jeszcze inni, że oni wyruszyli do raju na wejście duszy naszego Pana i [duszy] bandyty [łotra] (لیw). Ci zaś, którzy mówią, że oni pozostali przy życiu na długi czas i że niektórzy z nich żyli jeszcze za panowania Tytusa,

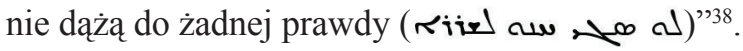

W encyklopedycznej formie autor wymienia różne opinie egzegetyczne bez podejmowania próby ich głębszej analizy i wyjaśnienia niejasności. Końcowa uwaga, w której Iszodad jednoznacznie precyzuje i odrzuca błędną koncepcję, skierowana została przeciw heretykom.

b) Egzegeza biblijna w komentarzach Teodora bar Koni. Teodor był nestoriańskim biskupem i nauczycielem w szkole w Kashkar. Z pewnymi wątpliwościami uznaje się lata 792/793 jako okres powstania jego głównego dzieła Scholion. W tym egzegetycznym opracowaniu w formie pytań i odpowiedzi na różne tematy zaczerpnięte z Peszitty Teodor wykorzystał schemat zaczerpnięty z greckich wzorców, zwłaszcza Teodora z Mopsuestii ${ }^{39}$. Katechetyczna forma przyjęta i rozwijana przez syryjskich egzegetów stała się wzorem dla późniejszych komentatorów arabskich i etiopskich. Liber scholiorum jako wykład nestoriańskiej doktryny przetrwało do dzisiaj, inne dzieła Teodora bar Koni jak Historia kościelna, traktaty, czy mowy pogrzebowe, zaginęły. Scholion zachował się w dwóch recenzjach, pierwsza starsza, w edycji Addaia Schera $^{40}$ i francuskim przekładzie Roberta Hespela i René Dragueta ${ }^{41}$. Druga recenzja, dłuższa, nazwana Urmia została przetłumaczona przez Hespela ${ }^{42}$. Dzieło Teodora to podręcznik teologii Kościoła wschodniosyryjskiego. Skomponowany został w formie 11 memre ( Kissos), z których 1-5 zawierają komentarze do Starego Testamentu, a 6-9 wyjaśniają teksty Nowego Testamentu. Należy jednak zaznaczyć, że nie są to komentarze w znaczeniu podstawowym i klasycznym, lecz formalnie stanowią ciąg pytań i odpowiedzi, którym posługiwali się wschodniosyryjscy egzegeci ${ }^{43}$. W memre 1-9 kwestie natury ściśle

${ }^{38}$ Isho'dad of Merv, In Matthaeum comm. XXII (komentarz do Mt 27, 53), ed. Gibson, s. 191. 19 - 192. 5, tłum. ang. Gibson, s. 114. 31-39, thum. własne.

39 Por. A.M. Butts, Theodoros bar Koni, w: Gorgias Encyclopedic Dictionary of the Syriac Heritage, s. 405. W. Wright (A Short History of Syriac Literature, s. 222) błędnie podaje rok 893 jako datę ustanowienia Teodora na biskupa Lāshōm. Zob. S. Brock, The Bible in the Syriac Tradition, Kottayam 1988, 66.

${ }^{40}$ Por. Theodorus bar Kōnī, Liber scholiorum, ed. A. Scher, CSCO 55, Scriptores Syri 19, Louvain 1960.

${ }^{41}$ Por. Theodorus bar Kōnī, Liber scholiorum, tłum. francuskie R. Hespel - R. Draguet: Théodore bar Koni, Livre des scolies (recension de Séert), CSCO 431-432, Scriptores Syri 187-188, Lovanii 1981-1982.

${ }^{42}$ Por. Theodorus bar Kōn̄̄, Liber scholiorum, thum. francuskie R. Hespel: Théodore bar Koni, Livre des scolies (recension d'Urmiah), CSCO 448, Scriptores Syri 194, Lovanii 1983. Zob. też wydanie tekstu: Theodorus bar Kōnī, Liber scholiorum (recension d'Urmiah), ed. R. Hespel, CSCO 447, Scriptores Syri 193, Lovanii 1983.

${ }^{43}$ Por. A.M. Butts, Embellished with Gold: The Ethiopic Reception of Syriac Biblical Exegesis, OC 97 (2013-2014) 140-141. 
egzegetycznej Teodor ubogaca różnymi koncepcjami filozoficznymi i teologicznymi. Fakt ten dał podstawy badaczom zagadnienia, aby Scholion został uznany za sumę teologiczną Kościoła wschodniosyryjskiego, a nie tylko komentarz egzegetyczny ${ }^{44} .10$ memrā jest antyislamską apologią chrześcijaństwa $^{45}$. Format pytań i odpowiedzi we wcześniejszych memre w tej księdze przybiera kształt dialogu między nauczycielem, który przemawia w imieniu chrześcijan, i uczniem, który reprezentuje stronę muzułmanów lub pogan. Ta memrā stanowi ważny przykład historycznego procesu kształtowania się relacji islam-chrześcijaństwo w okresie wczesnych Abbasydów. 11 memrā Scholionu jest opisem wszystkich herezji ,przed i po Chrystusie" ${ }^{46}$. Bar Koni wymienia m.in. zaratustrian, mandejczyków i manichejczyków, różnych gnostyków, kukean (kukitów), ofitów i bardesanitów. Widoczny jest tutaj wpływ Panarionu Epifaniusza z Salaminy ${ }^{47}$.

Jako przykład charakterystycznej w egzegezie syryjskiej różnorodności interpretacyjnej może posłużyć komentarz do Księgi Rodzaju, w którym bar Koni wyjaśnia znaczenie utworzenia Ewy z boku Adama (Mimrā II 52):

„Dlaczego Ewa została wyciagnięta z boku (r) [Bóg] nie utworzył kobiety z ziemi, aby nie wydawało się, że ona jest obca mężczyźnie. I nie wziął jej z jego [Adama] pleców, aby on nie uważał jej za godną pogardy; ani z jego przodu/części przedniej, aby ona nie była arogancka; ale z jego prawe-

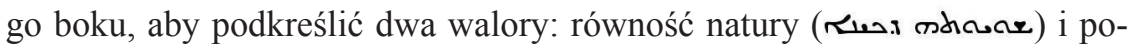
trzebę pomocy mężczyźnie. Bok (مiظ) bowiem jest takim miejscem, które łączy/jednoczy i jest połączony z dwóch stron; każde istniejące zwierzę jest związane dwoma bokami; i jak prawy bok ukrywa żebro ( $\sim \cup \sim)$, podobnie mężczyzna [chroni] kobietę. «[Bóg] zesłał głęboki sen (علعr) na Adama», co znaczy, że czuwał w całkowitym śnie, aby uniknąć w doświadczeniu cierpienia potraktowania kobiety z nienawiścią/odraza, albo [gdyby to się odbyło] bez żadnego bólu, mężczyzna nie sądził, że ona nie podlega prawom natury. Oczywiście w tym żebrze (

Urozmaiceniem w tej literackiej strukturze są wyjaśnienia trudnych wyrazów i fraz, które w VIII w. mogły już być niezrozumiałe dla czytelników

${ }^{44}$ Por. S.H. Griffith, Theodore bar Koni's Scholion: A Nestorian Summa Contra Gentiles from the First Abbasid Century, w: East of Byzantium: Syria and Armenia in the Formative Period, ed. N. Garsoian - T. Mathews - R.Thomson, Washington 1982, 53-72.

${ }^{45}$ Por. tenże, Chapter Ten of the Scholion: Theodore Bar Kônî’s Apology for Christianity, OCP 47 (1981) 158-188.

${ }^{46}$ Por. Theodorus bar Kōn̄̄, Liber scholiorum, II, ed. A. Scher, CSCO 69, Scriptores Syri 26, Lovain 1960, 284.

${ }^{47}$ Por. Butts, Theodoros bar Koni, s. 405-406. Krytyczną opinię na temat wpływu Epifaniusza z Salaminy na kształt listy heretyków wymienionych przez Teodora podaje J.P. Asmussen (Bar Kōnay, Theodore, w: Encyclopaedia Iranica, vol. 3, fasc. 7, ed. E. Yarshater, London - New York 1989, 737-738).

${ }^{48}$ Theodorus bar Kōnī, Liber scholiorum, CSCO 55, 70, 19 - 71, 10, tłum. własne. 
biblijnego tekstu. Dodatkowo trudność, z mniejszą grupą tych terminów, mogła wynikać ze zbyt mechanicznego przekładu hebrajskiego źródła. Podobnie jak w przypadku Iszodada egzegeza Teodora bar Koni bazuje przede wszystkim na komentarzach Teodora z Mopsuestii. Jak podkreśla sam bar Koni, jego Scholion został adresowany do tych wszystkich, którzy zapragnęli poznać komentarze „błogosławionego interpretatora”" ${ }^{49}$. Na wielu miejscach tego podręcznika uderza podobieństwo do Iszodada z Merw. Zagadnienie relacji między tymi dziełami nie zostało jeszcze do końca wyjaśnione, aczkolwiek najprawdopodobniej wszystkie te wymienione komentarze czerpały ze wspólnego źródła. W porównaniu do egzegezy Iszodada interpretacje bar Koni wydają się ściślej nawiązywać do myśli interpretatora, mniej uwagi poświęcając duchowej egzegezie, co wyraził w ocenie małej wartości Pieśni nad Pieśnia$\mathrm{mi}^{50}$. Według Hespela Iszodad z Merw nie był zależny od Teodora bar Koni, lecz obaj zależeli od starszego komentarza, który prawdopodobnie stanowił dla nich wspólne źródło ${ }^{51}$. Zarówno dla Teodora bar Koni jak i dla Iszodada egzegeza historyczna (rułurł) różni się w sposób zasadniczy od egzegezy alegorycznej (rudin ala). Pierwsza prowadzi do prawdy i wiary, druga zaś do bezbożności, bluźnierstwa i kłamstwa. Obaj egzegeci oskarżają Orygenesa, że jako twórca metody alegorycznej zastosował w lekturze ksiąg Pisma Świętego narzędzia literatury poetów i platoników ${ }^{52}$.

Badane w artykule syryjskie komentarze cechuje oryginalna metoda rzadko spotykana w łacińskiej i greckiej egzegezie. Zarówno Afrahat Pers i Efrem Syryjczyk, jak i Iszodad z Merw i Teodor bar Koni zestawiali różne propozycje i interpretacje jednego biblijnego wydarzenia. W ujęciu tych egzegetów aprobata różnorodności jest świadectwem znajomości istoty Pisma Świętego. Mozaika interpretacji stanowi podstawową cechę oryginalności biblijnych komentarzy Syryjczyków. Materiału do wyjaśnień dostarczała im wnikliwa obserwacja dzieła stworzenia. Możliwe, że istotnym czynnikiem przyjętej metodologii hermeneutycznej była znajomość judaizmu i egzegetycznego

\footnotetext{
${ }^{49}$ Tamże, CSCO 69, 231.

${ }^{50}$ Por. tamże, CSCO 55, 324.

${ }^{51}$ Por. R. Hespel, Introduction, w: CSCO 431, 5. Hespel powołuje się na opinię Van den Eynde'a (Préface, w: Commentaire d'Išo 'dad de Merv sur l'Ancien Testament, I: Genèse, thum. francuskie C. van den Eynde, CSCO 156, Scriptores Syri 75, Louvain 1955, XI-XII) i Baumstarka (Geschichte der syrischen Literatur, s. 218, nota 9).

${ }^{52}$ Por. Theodorus bar Kōnī, Liber scholiorum, CSCO 55, 356, 9 - 359, 8 (fragment zatytułowany

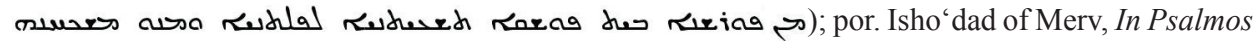
comm., Prol. 12, ed. C. van den Eynde: Commentaire d'Isho'dad de Merv sur l'Ancien Testament, VI: Psaumes, CSCO 433, Scriptores Syri 185, Lovanii 1981, 11-12, tłum. francuskie C. van den Eynde: Commentaire d'Isho'dad de Merv sur l'Ancien Testament, VI: Psaumes, CSCO 434, Scriptores Syri 186, Lovanii 1981, 13-14.
} 
warsztatu pracy rabinów. Analizy komentarzy biblijnych Iszodada z Merw i Teodora bar Koni pozwoliły odkryć ewolucję w egzegezie nestoriańskiej, w której dominowała tradycja antiocheńska. Wschodni Syryjczycy z VIII i IX w. intensywnie wykorzystywali metodę interpretacyjnej różnorodności, którą w IV w. posługiwali się Afrahat i Efrem Syryjczyk.

\author{
BIBLICAL EXEGESIS IN THE SYRIAC COMMENTARIES \\ OF APHRAHAT, EPHRAIM THE SYRIAN, ISHODAD OF MERV \\ AND THEODORE BAR KONI. \\ THE OUTLINE OF ISSUES
}

(Summary)

The Syriac commentaries analysed in the article are characterised by an original method, rarely appearing in the Latin or Greek exegesis. Both Aphrahat the Persian and Ephraim the Syrian, as well as Ishodad of Merv and Theodore bar Koni juxtaposed various propositions and interpretations of one Biblical event. In the view of these exegetes, the affirmation of diversity was the evidence of the knowledge of the essence of Holy Scripture. Such a mosaic of interpretations constitutes a primary feature proving the originality of the Syrians' Biblical commentaries. Most significantly, it was the astute observation of the work of creation that provided them with the material for their interpretations. It is also possible that the knowledge of Judaism and exegetical techniques of rabbis played a crucial role in the adopted hermeneutical methodology. The analyses of Ishodad of Merv's and Theodore bar Koni's commentaries led to the discovery of the evolution in Nestorian exegesis, dominated by Antiochian tradition. East Syrians from the $8^{\text {th }}$ and $9^{\text {th }}$ centuries widely employed the interpretative method of diversity, previously used by Aphrahat and Ephraim the Syrian in the $4^{\text {th }}$ century.

Key words: Aphrahat, Ephraim the Syrian, Ishodad of Merv, Theodore bar Koni, nestorian exegesis, Syriac language.

Slowa kluczowe: Afrahat Pers, Efrem Syryjczyk, Iszodad z Merw, Teodor bar Koni, egzegeza nestoriańska, język syryjski.

\title{
BIBLIOGRAFIA
}

\section{Źródła}

Acta Judae Thomae, ed. W. Wright: The Hymn of Judas Thomas the Apostle in the country of the Indians, w: Apocryphal Acts of the Apostles, vol. 1: The Syriac Texts, London 1871, $\mathbf{2} \mathbf{i}-\downarrow_{\mathbf{i}} \mathbf{i}$, thum. M. Starowieyski: Dzieje Apostola Judy Tomasza, w: Apokryfy Nowego Testamentu. Apostołowie, część I: Andrzej, Jan, Pawet, Piotr, Tomasz, red. M. Starowieyski, Kraków 2007, 590-695. 
Aphrantes, Demonstrationes, ed. J. Parisot: Aphraatis Sapientis Persae Demonstrationes, PSyr 1, Paris 1894, 1980², PSyr 2, Paris 1907, 1980², thum. A. Uciecha: Afrahat, O poście (Demonstratio tertia. De ieiunio, PSyr 1, 97-136), SSHT 42 (2009) fasc. 1, 85-96; Afrahat, $O$ wojnach (Demonstratio quinta. De bellis, PSyr 1, 184-237), SSHT 43 (2010) fasc. 2, 248-262; Afrahat, O synach przymierza (Demonstratio sexta. De monachis, PSyr 1, 240-312), SSHT 44 (2011) fasc. 1, 177-197.

Ephraem Syrus, Commentarius in Diatessaron, thum. francuskie L. Leloir: Éphrem de Nisibe, Commentaire de L'Évangile Concordant ou Diatessaron, SCh 121, Paris 1966.

Ephraem Syrus, Hymnus de fide 81 (De Margarita I), ed. E. Beck, CSCO 154, Scriptores Syri 73, Louvain 1955, 248-251, tłum. niemieckie E. Beck, w: Des Heiligen Ephraem des Syrers ,, Hymnen de Fide”, CSCO 155, Scriptores Syri 74, Louvain 1955, 211-213.

IsHo'DAD OF Merv, In Matthaeum comm., ed. M.D. Gibson, w: The Commentaries of Isho 'dad of Merv, Bishop of Hadatha (c. 850 A. D.) in Syriac and English, vol. 2: Matthew and Mark in Syriac, Horae Semiticae 6, Cambridge 1911, 2-203, thum. M.D. Gibson, w: The Commentaries of Isho 'dad of Merv, Bishop of Hadatha (c. 850 A. D.) in Syriac and English, Translation, vol. 1: Translation, Horae Semiticae 5, Cambridge 1911, 1-122.

Isho'DAD of Merv, In Psalmos comm, ed. C. van den Eynde: Commentaire d'Isho'dad de Merv sur l'Ancien Testament, VI: Psaumes, CSCO 433, Scriptores Syri 185, Lovanii 1981, tłum. francuskie C. van den Eynde: Commentaire d'Isho'dad de Merv sur l'Ancien Testament, VI: Psaumes, CSCO 434, Scriptores Syri 186, Lovanii 1981.

Pseudo-Epiphanius, Physiologus, PG 43, 517-534.

THEODORUS BAR KōNİ, Liber scholiorum (recension d'Urmiah), ed. R. Hespel, CSCO 447, Scriptores Syri 193, Lovanii 1983; thum. francuskie R. Hespel: Théodore bar Koni, Livre des scolies (recension d'Urmiah), CSCO 448, Scriptores Syri 194, Lovanii 1983.

THEODORUS BAR KōNī, Liber scholiorum (recension d'Urmiah), Les collections annexées par Sylvain de Qardu, ed. R. Hespel, CSCO 464, Scriptores Syri 197, Lovanii 1984; tłum. francuskie R. Hespel: Théodore bar Koni, Livre des scolies (recension d'Urmiah), Les collections annexées par Sylvain de Qardu, CSCO 465, Scriptores Syri 198, Lovanii 1984.

TheOdorus BAR KōNī, Liber scholiorum (recension de Séert), I, ed. A. Scher, CSCO 55, Scriptores Syri 19, Louvain 1960; II, ed. A. Scher, CSCO 69, Scriptores Syri 26, Lovain 1960; tłum. francuskie R. Hespel - R. Draguet: Théodore bar Koni, Livre des scolies (recension de Séert), I: Mimrè I-V, CSCO 431, Scriptores Syri 187, Lovanii 1981; II: Mimrè VI-XI, CSCO 432, Scriptores Syri 188, Lovanii 1982.

\section{Opracowania}

Asmussen J.P., Bar Kōnay, Theodore, w: Encyclopaedia Iranica, vol. 3, fasc. 7, ed. E. Yarshater, London - New York 1989, 737-738.

BaArs W., New Syro-Hexaplaric Texts. Edited, Commented upon and Compared with the Septuagint, Leiden 1968.

BAUMSTARK A., Geschichte der syrischen Literatur mit Ausschluss der christlich-palästinensischen Texte, Bonn 1922.

Brock S., The Bible in the Syriac Tradition, Kottayam 1988.

Brockelmann C., Lexicon Syriacum, Halis Saxonum 1928.

Butts A.M., Embellished with Gold: The Ethiopic Reception of Syriac Biblical Exegesis, OC 97 (2013-2014) 137-159.

Butts A.M., Theodoros bar Koni, w: Gorgias Encyclopedic Dictionary of the Syriac 
Heritage, ed. S.P. Brock - A.M. Butts - G.A. Kiraz - L. Van Rompay, Piscataway 2011, 405-406.

El-Khoury N., Hermeneutics in the Works of Ephraim the Syrian, w: IV Symposium Syriacum, OCA 229, Roma 1987, 93-110.

Eynde C. van den, Préface, w: Commentaire d'Išo 'dad de Merv sur l'Ancien Testament, I: Genèse, tłum. francuskie C. van den Eynde, CSCO 156, Scriptores Syri 75, Louvain 1955, I-XXV.

Fizjologi i Aviarium. Średniowieczne traktaty o symbolice zwierząt, thum. i oprac. S. Kobielus, Kraków 2005.

Graffin F., Les Hymnes sur la Perle de S. Ephrem, „L'Orient Syrien” 12 (1967) 129-150.

Griffith S.H, Chapter Ten of the Scholion: Theodore Bar Kônî's Apology for Christianity, OCP 47 (1981) 158-188.

Griffith S.H., Theodore bar Koni's Scholion: A Nestorian Summa Contra Gentiles from the First Abbasid Century, w: East of Byzantium: Syria and Armenia in the Formative Period, ed. N. Garsoian - T. Mathews - R.Thomson, Washington 1982, 53-72.

Hespel R., Introduction, w: Théodore bar Koni, Livre des scolies (recension de Séert), I: Mimrè I-V, ed. R. Hespel - R. Draguet, CSCO 431, Scriptores Syri 187, Lovanii 1981, 1-22.

Jansma T., Théodore de Mopsueste. Interprétation du „Livre de la Genèse”. Fragments de la version syriaque (B.M. Add. 17, 189, fol. 17-21), „Muséon” 75 (1962) 63-92.

JAŻDŻEWSKA K., O pochodzeniu ,Fizjologa”, WST 15 (2002) 85-100.

LEONHARD C., Ishodad of Merw's Exegesis of the Psalms 119 and 139-147: A Study of His Interpretation in the light of the syriac translation of Theodore of Mopsuestia's Commentary, CSCO 585, Scriptores Syri 107, Lovanii 2005.

Mathews E.G. Jr. - Amar J.P., General introduction, w: St. Ephrem the Syrian, Selected Prose Works (Commentary on Genesis, Commentary on Exodus, Homily on our Lord, Letter to Publius), The Fathers of the Church 91, transl. E.G. Mathews Jr. - J.P. Amar, ed. K. McVey, Washington 1994, 4-56.

ModzelewsKa B., Iszodad z Merw, EK VII 542-543.

Myszor W., Sprzedawca peret w „Dziejach Piotra i dwunastu Apostołów” z VI Kodeksu z Nag Hammadi, VoxP 7 (1987) t. 12-13, 303-305.

Myszor W., Symbolika perty w utworach gnostyków i manichejczyków, „Rocznik Muzeum Narodowego w Warszawie" 36 (1992) 41-48.

Pereira A.S.R., Studies in Aramaic Poetry (c. 100 B.C.E.-c.600 C.E.). Selected Jewish, Christian and Samaritan Poems, Assen 1997.

Petersen W.L., Problems in the Syriac New Testament and how Syrian Exegetes solved them, w: The Peshitta. Its use in literature and the liturgy. Papers Read at the Third Peshitta Symposium, ed. Bas ter Haar Romeny, Leiden - Boston 2006, 53-74.

Rompay L. Van, Between the school and the monk's cell: the syriac Old Testament commentary tradition, w: The Peshitta. Its use in literature and the liturgy. Papers Read at the Third Peshitta Symposium, ed. Bas ter Haar Romeny, Leiden - Boston 2006, 27-51.

Rompay L. Van, Isho 'dad of Merv (floruit circa 850) [Church of the East], w: Gorgias Encyclopedic Dictionary of the Syriac Heritage, ed. S.P. Brock - A.M. Butts - G.A. Kiraz - L. Van Rompay, Piscataway 2011, 216-217.

Salvesen A.G., Syro-Hexapla, w: Gorgias Encyclopedic Dictionary of the Syriac Heritage, ed. S.P. Brock - A.M. Butts - G.A. Kiraz - L. Van Rompay, Piscataway 2011, 394-395.

StARowIEYSKi M., Iszodad z Merw, SWPW 96.

Thesaurus Syriacus, ed. R. Payne Smith, t. 1-2, Oxonii 1879-1901.

Wright W., A Short History of Syriac Literature, London 1894. 